\title{
Nitrate concentration in lettuce leaves depending on photosynthetic photon flux and nitrate concentration in the nutrient solution
}

\author{
Nilton Nélio Cometti'; Madlles Q Martins²; Cintia Aparecida Bremenkamp",3 José Arcanjo Nunes² \\ ${ }^{1}$ IFB-Instituto Federal de Brasília, SQN 415, Bloco A, Apto. 101, 70878-010 Brasília-DF; nncometti@hotmail.com; www.niltoncometti. \\ com.br; ${ }^{2}$ FFES-CCA, Alto Universitário, s/n, 29500-000 Alegre-ES; mqm_agroline@hotmail.com; cintia.bremenkamp@gmail.com; \\ nunesarcanjo@terra.com.br; ${ }^{3}$ UENF-CCTA, Av. Alberto Lamego 2000,28013-602 Campos dos Goytacazes-RJ
}

\begin{abstract}
The nitrate accumulation in plant tissues can occur due to low light availability. However, published studies have not linked nitrate accumulation to photosynthetic photon flux (PPF) measured during the growing period. This study aimed to evaluate the effect of the reduction of photosynthetic photon flux and the concentration of nitrate in the nutrient solution on agronomic characteristics and accumulation of nitrate in lettuce grown in hydroponics. The trial design was entirely randomized in a factorial scheme (4 x 2) with three repetitions, and four shading levels: $0,30,50$, and $80 \%$ and two nitrate levels in nutrient solution: 5 and $10 \mathrm{mmol} \mathrm{L}^{-1}$. The dry matter production decreased directly and linearly with the reduction of light. The lowest level in nitrate solution also led to reduction in dry mass yield. The maximum accumulation of nitrate reached $966.3 \mathrm{mg} \mathrm{kg}^{-1}$ fresh mass, with PPF of $118 \mu \mathrm{mol} / \mathrm{m}^{2} / \mathrm{s}$ and $140 \mathrm{mg} \mathrm{L}^{-1}$ of $\mathrm{N}_{-\mathrm{NO}_{3}{ }^{-1}}$ (below the maximum levels recommended by the European Union), and the minimum of $200 \mathrm{mg} \mathrm{kg}^{-1}$ with PPF of $455 \mu \mathrm{mol} / \mathrm{m}^{2} / \mathrm{s}$ and 70 $\mathrm{mg} \mathrm{L}^{-1}$ of $\mathrm{N}_{-\mathrm{NO}_{3}}^{-1}$ in the nutrient solution. The reduction of nitrate in the nutrient solution from 140 to $70 \mathrm{mg} \mathrm{L}^{-1}$ led to the reduction of nitrate accumulation in shoots, but also caused a decrease in the production of phytomass of shoots, as well as reduced leaf area significantly.
\end{abstract}

Keywords: Lactuca sativa L., hydroponic crop, shading, nitrate accumulation.

\section{RESUMO}

Teores de nitrato em alface sob fluxo de fótons fotossintéticos e concentração de nitrato na solução nutritiva

O acúmulo de nitrato nos tecidos vegetais pode ocorrer em função da baixa disponibilidade luminosa. Entretanto, trabalhos publicados não têm relacionado acúmulo de nitrato com o fluxo de fótons fotossintéticos (PPF) medidos durante o período de cultivo. Neste trabalho objetivou-se avaliar características agronômicas e acúmulo de nitrato em plantas de alface cultivadas em hidroponia em função da redução no fluxo de fótons fotossintéticos e da concentração de nitrato na solução nutritiva. $\mathrm{O}$ delineamento experimental foi inteiramente ao acaso, em esquema fatorial 4 x 2, com três repetições, sendo quatro níveis de sombreamento: $0,30,50$ e $80 \%$ e dois níveis de nitrato na solução: 5 e $10 \mathrm{mmol} \mathrm{L}^{-1}$. A produção de massa seca caiu direta e linearmente com a redução da luminosidade. $\mathrm{O}$ menor nível de nitrato na solução também acarretou redução no rendimento de massa seca. A concentração máxima de $\mathrm{NO}_{3}{ }_{3}^{-}$observada alcançou $966,3 \mathrm{mg} \mathrm{kg}^{-1}$ de massa fresca, com o PPF de $118 \mu \mathrm{mol} / \mathrm{m}^{2} / \mathrm{s}$ e 140 $\mathrm{mg} \mathrm{L}^{-1}$ de $\mathrm{N}^{-N_{3}}{ }_{3}^{-1}$ (abaixo dos níveis máximos preconizados pela União Européia) e a mínima, $200 \mathrm{mg} \mathrm{kg}^{-1} \mathrm{com} \mathrm{PPF} \mathrm{de} 455 \mu \mathrm{mol} / \mathrm{m}^{2} / \mathrm{s}$ e $70 \mathrm{mg} \mathrm{L}^{-1}$ de $\mathrm{N}_{-} \mathrm{NO}_{3}^{-1}$ na solução nutritiva. A redução do nitrato na solução nutritiva de 140 para $70 \mathrm{mg} \mathrm{L}^{-1}$ levou à redução do acúmulo de nitrato na parte aérea, porém também promoveu a redução na produção da fitomassa da parte aérea, bem como a redução na área foliar de forma significativa.

Palavras-chave: Lactuca sativa L., cultivo hidropônico, sombreamento, acúmulo de nitrato.

(Recebido para publicação em 26 de julho de 2010; aceito em 10 de outubro de 2011) (Received on July 26, 2010; accepted on October 10, 2011)

L ettuce (Lactuca sativa) is the most cultivated vegetable in Brazil. In hydroponics, lettuce is also the highest expression crop, both by the quantity and the quality that reaches compared to conventional tillage. This demonstrates the preference of the population in the consumption of lettuce in relation to other broadleaves (Cometti \& Furlani, 2009a). Lettuce leaves are usually eaten raw and without any restriction to daily intake. However, lettuce has a great ability to accumulate nitrate in their leaves (Eysinga \& Van Roorda, 1984), which can be harmful to human health
(Wright \& Davison, 1964). Nitrate is regarded as a possible precursor of carcinogenic nitrosamines (Addiscott, 2006; Cometti \& Furlani, 2009a). However, it is still not consensus, nor is it known precisely, if the intake of nitrate is beneficial or harmful to human health (Light et al., 2008).

The concentrations of nitrate in commercial lettuce vary considerably. Nitrate levels ranging from 26 to 2568 $\mathrm{mg} \mathrm{kg}{ }^{-1}$ fresh weight have been found. Plants grown in hydroponic systems showed higher levels compared to those grown in conventional systems
(Beninni et al., 2002). Among the foods consumed by humans, plants represent between 72 and $94 \%$ of daily intake of nitrate (Santamaria, 1997). The acceptable nitrate content in lettuce for human consumption vary with the season and have not been stipulated by the Brazilian law, therefore European indexes have been adopted in Brazil. Thus, the European Union establishes the maximum permissible levels from 3,500 to 4,500 mg N-NO ${ }_{3}^{-} \mathrm{kg}^{-1}$ fresh weight for the winter season and 2,500 $\mathrm{mg}$ of N-NO${ }_{3}^{-} \mathrm{kg}^{-1}$ for the summer crops (Europe, 2009). The accumulation of 
nitrate in plant tissues occurs when there is an imbalance between the absorption and assimilation of this ion or ammonium, and surplus quantities are stored in the vacuoles to be assimilated later (Andriolo, 1999). The main factors that affect nitrate accumulation in plants are genetic, environmental, amount and proportion of $\mathrm{N}$-carrier and the amount of molybdenum provided. Light intensity seems to be among the environmental factors that most influences nitrate accumulation in plants, because plants usually accumulate more nitrate when they are subjected to low light intensity (Ohse, 2000). This explains why nitrate levels in vegetables are higher in countries with low availability of radiation, such as Northern Europe. Despite de fact that Brazil's conditions of solar radiation apparently do not promote accumulation of nitrate in lettuce, samples of hydroponic lettuce with levels close to the limits by European laws have been reported by Benini et al. (2002) who found out samples reaching $2,568 \mathrm{mg} \mathrm{kg}^{-1}$ fresh weight. Hydroponic crops are associated with the use of sun protection, usually done with agricultural plastic and shade screen. The study of Novo et al. (2008) correlates accumulation of nitrate with shading (percentage), using the unit $\%$ of shading. This unit, however, does not allow extrapolation to areas with different intensities of solar radiation. Thus, it is necessary to study the accumulation of nitrate as a function of photosynthetic photon flux, This is a variable that can be measured with simple equipment, enabling the extrapolation of the shade effect on the accumulation of nitrate to other locations.

The objective of this study was to evaluate agronomic characteristics and nitrate accumulation in lettuce grown in hydroponics as a function of photosynthetic photon flux and nitrate content in the nutrient solution.

\section{MATERIAL AND METHODS}

The experiment was carried out from September $23^{\text {th }}$ to October $16^{\text {th }}$ 2009 (early spring), in a greenhouse covered with transparent plastic film and a thermal reflective screen inside (Aluminet $^{\circledR}$ ), at the Centro de Ciências Agrárias of Universidade Federal do Espirito Santo, located in Alegre, Espirito Santo state, Brazil (2045'S, $41^{\circ} 32^{\prime} \mathrm{W}$, altitude $271 \mathrm{~m}$ ). The climate is Cwa (Köppen), characterized by a dry winter and rainy summer. Lettuce cultivar Vera was seeded in phenolic foam (cubes of $2 \times 2 \times 2 \mathrm{~cm}$ ), irrigated with water until germination. From then, plants received nutrient solution (Furlani et al., 1999) with $\mathrm{EC}=1.59$ $\mathrm{mS} \mathrm{m}^{-1}$ and $1.44 \mathrm{mS} \mathrm{m}^{-1}$ for the nutrient solutions 1 and 2, respectively. Thinning was done at 21 days after sowing (DAS), leaving one plant per cell. Then the seedlings were transplanted to plastic pots containing three liters of nutrient solution.

The experimental design was entirely randomized in a factorial $2 \times 4$, with two nutrient nitrate concentration solutions (140 and $70 \mathrm{mg} \mathrm{L}^{-1}$ ) and four shading levels $(0,30,50,80 \%)$, which average of photosynthetic photon flux (PPF) were, respectively 455, 243, 146 and 118 $\mathrm{mmol} / \mathrm{m}^{2} / \mathrm{s}$ (Table 1). There were three replicates and a pot per plot. Shading was carried out in small bamboo houses (0.8 $\mathrm{m}$ high, $0.7 \mathrm{~m}$ wide and $1.0 \mathrm{~m}$ in length), covered with polyethylene UV screens (Sombrite ${ }^{\circledR}$ ) to reduce brightness in different shading treatments $(30,50$ and $80 \%$ ).

Solutions had the following nutrient concentrations in $\mathrm{mg} \mathrm{L}^{-1}$ : the first with $140 \mathrm{~N}^{-\mathrm{NO}_{3}}{ }_{3}^{-} ; 26.18 \mathrm{P}_{-} \mathrm{H}_{2} \mathrm{PO}_{4}^{-} ; 171.47 \mathrm{~K}^{+}$; $128.67 \mathrm{Ca}^{++} ; 17.46 \mathrm{Mg}^{++} ; 0.5 \mathrm{~B} ; 0.05$ $\mathrm{Cu}$; 0.5 Mn; 0.05 Mo; 0.1 Zn; 24.37 S and $2 \mathrm{Fe}$; the second nutrient solution was the same except that contained $70 \mathrm{~N}-\mathrm{NO}_{3}$. The sources of major nutrients were commercial fertilizers: potassium nitrate, magnesium sulfate and monopotassium phosphate (MKP). For the other nutrients, p.a. salts were used: $4 \mathrm{H}_{2} \mathrm{O}$ calcium nitrate, calcium chloride, boric acid, $5 . \mathrm{H}_{2} \mathrm{O}$ copper sulfate, manganese sulfate, anhydrous sodium molybdate, $7 . \mathrm{H}_{2} \mathrm{O}$ zinc sulfate and Fe-EDTA (13\%). The pH was

Table 1. Temperature of leaves and nutrient solution, and photosynthetic photon flux under shading treatments (temperatura de folha e da solução nutritiva, e fluxo de fótons fotossintéticos sob os tratamentos de sombreamento). Alegre, UFES, 2009.

\begin{tabular}{|c|c|c|c|c|c|}
\hline \multirow{3}{*}[\mathrm{NO}_{3}^{-}]{} & \multirow{3}{*}{ Hour } & \multirow{2}{*}{$\begin{array}{c}0 \\
\text { (unshaded) }\end{array}$} & \multicolumn{3}{|c|}{ Shading (\%) } \\
\hline & & & 30 & 50 & 80 \\
\hline & & \multicolumn{4}{|c|}{ Leaf temperature $\left({ }^{\circ} \mathrm{C}\right)$} \\
\hline 140 & 09:00 & 26.8 & 27.0 & 27.9 & 27.7 \\
\hline 140 & $12: 00$ & 27.5 & 27.7 & 27.5 & 29.5 \\
\hline 140 & $15: 00$ & 26.4 & 26.9 & 27.3 & 28.5 \\
\hline 70 & 09:00 & 26.2 & 26.7 & 27.0 & 28.0 \\
\hline 70 & $12: 00$ & 27.2 & 27.8 & 29.2 & 29.7 \\
\hline \multirow[t]{2}{*}{70} & $15: 00$ & 26.5 & 27.0 & 28.0 & 28.7 \\
\hline & & \multicolumn{4}{|c|}{ Temperature of nutrient solution $\left({ }^{\circ} \mathrm{C}\right)$} \\
\hline 140 & 09:00 & 29.8 & 24.6 & 25.0 & 24.3 \\
\hline 140 & $12: 00$ & 29.0 & 27.3 & 27.6 & 26.9 \\
\hline 140 & $15: 00$ & 30.0 & 27.7 & 28.5 & 27.2 \\
\hline 70 & 09:00 & 24.9 & 24.3 & 24.3 & 24.2 \\
\hline 70 & $12: 00$ & 28.4 & 27.2 & 27.1 & 27.0 \\
\hline \multirow[t]{6}{*}{70} & $15: 00$ & 30.3 & 28.5 & 28.3 & 27.4 \\
\hline & & \multicolumn{4}{|c|}{ Photosynthetic photon flux $\left(\mu \mathrm{mol} / \mathrm{m}^{2} / \mathrm{s}\right)$} \\
\hline & 09:00 & 621 & 322 & 190 & 153 \\
\hline & $12: 00$ & 529 & 285 & 175 & 146 \\
\hline & $15: 00$ & 173 & 102 & 59 & 80 \\
\hline & Average* & 455 & 243 & 146 & 118 \\
\hline
\end{tabular}

*Average used as independent variable for regressions (valores médios utilizados como variável independente nas regressões). 
adjusted to 5.5 with $\mathrm{NaOH}$ solution. The amount of solution was refilled daily and completely replaced every week. The solutions were calculated using a spreadsheet from Furlani \& Cometti (2009b).

Leaf temperature was determined on the fifth leaf from the apex to the base, and nutrient solution temperature was measured using an infrared digital thermometer, model Ad Therm Kids brand HuBDIC. The photosynthetic photon flux was measured by a radiometer Quantum Meter, model SS-QMSW from Apogee Instruments Inc, USA, positioning the bar with 12 sensors toward the zenith over the plant canopy. Air temperature was determined using a mercury thermometer fixed inside the greenhouse. Leaf temperature, temperature of nutrient solution and air temperature (Table 1), and the PPF were measured every 2 days after transplanting seedlings to pots. The mean air temperature inside the greenhouse during trial was 30,34, and $32^{\circ} \mathrm{C}$ at 9:00 am, 12:00, and 3:00 pm, respectively.

Plants were harvested 47 days after sowing, and divided into roots and shoots to determined: shoot fresh mass (SFM), root fresh mass (RFM), shoot dry mass (SDM) and root dry mass (RDM), plant height $(\mathrm{PH})$, plant diameter, stem length (SL), root length (RL) and leaf area (LA) and leaf number (LN) of plants. Three leaves of lettuce from each plot were collected to determine the leaf area, being one of the apical third, one of the middle and another of the basal third. These leaves were weighed to obtain mass and scanned (with Multifunction Samsung SCX-4100®) to obtain the area of three sheets expressed in $\mathrm{m}^{2}$. The total area of the plant was calculated proportional to the mass of the plant. Nitrate content in dry matter was determined after extraction with water (Cataldo et al., 1975). The data were submitted to analysis of variance (SigmaStat, SPSS Science, Chicago, Ill.) and analyzed by regression (SigmaPlot, SPSS, Chicago, Ill), using the average measured photosynthetic photon flux (Table 1) as the independent variable for analysis of the shading treatments. T-test was used to compare the nitrate levels in the nutrient solution by adopting a 5\% probability level.

\section{RESULTS AND DISCUSSION}

There were no significant interactions between levels of shading and nitrate content in the nutrient solution for all variables.
The production of fresh and dry shoot mass and root (SFM, RFM, SDM, and RDM) increased with the photosynthetic photon flux (PPF). The elevation of the PPF 118 (with $80 \%$ shading) to 455 $\mathrm{mol} / \mathrm{m}^{2} / \mathrm{s}$ (without shading) increased SFM from 39.6 to 152.7 , SDM from 1.2 to 8.7 , RFM from 6.0 to 21.8 and RDM from 0.4 to $1.6, \mathrm{~g} /$ plant, with 140 $\mathrm{mg} \mathrm{L}^{-1}$ of $\mathrm{NO}_{3}^{-}$. With $70 \mathrm{mg} \mathrm{L}^{-1}$ of $\mathrm{NO}_{3}^{-}$,

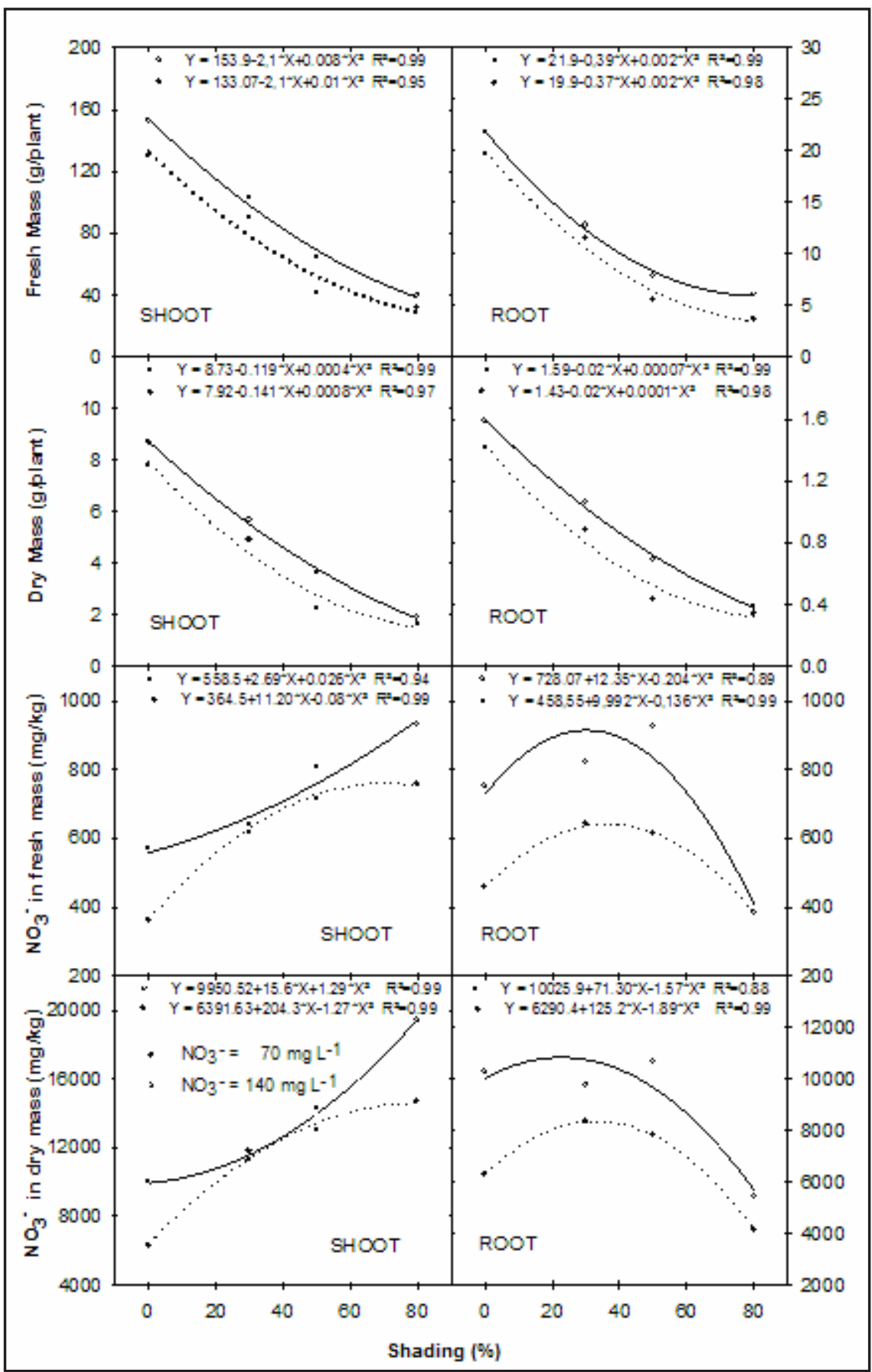

Figure 1. Production of phytomass and nitrate accumulation by lettuce in hydropoonics at different levels of photosynthetic photon flux and $\mathrm{N}_{-} \mathrm{NO}_{3}^{-1}$ in the nutrient solution (produção de fitomassa e acúmulo de nitrato na alface cultivada em hidroponia em diferentes níveis de

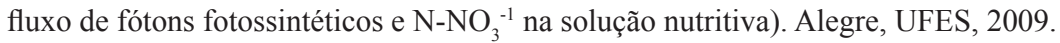




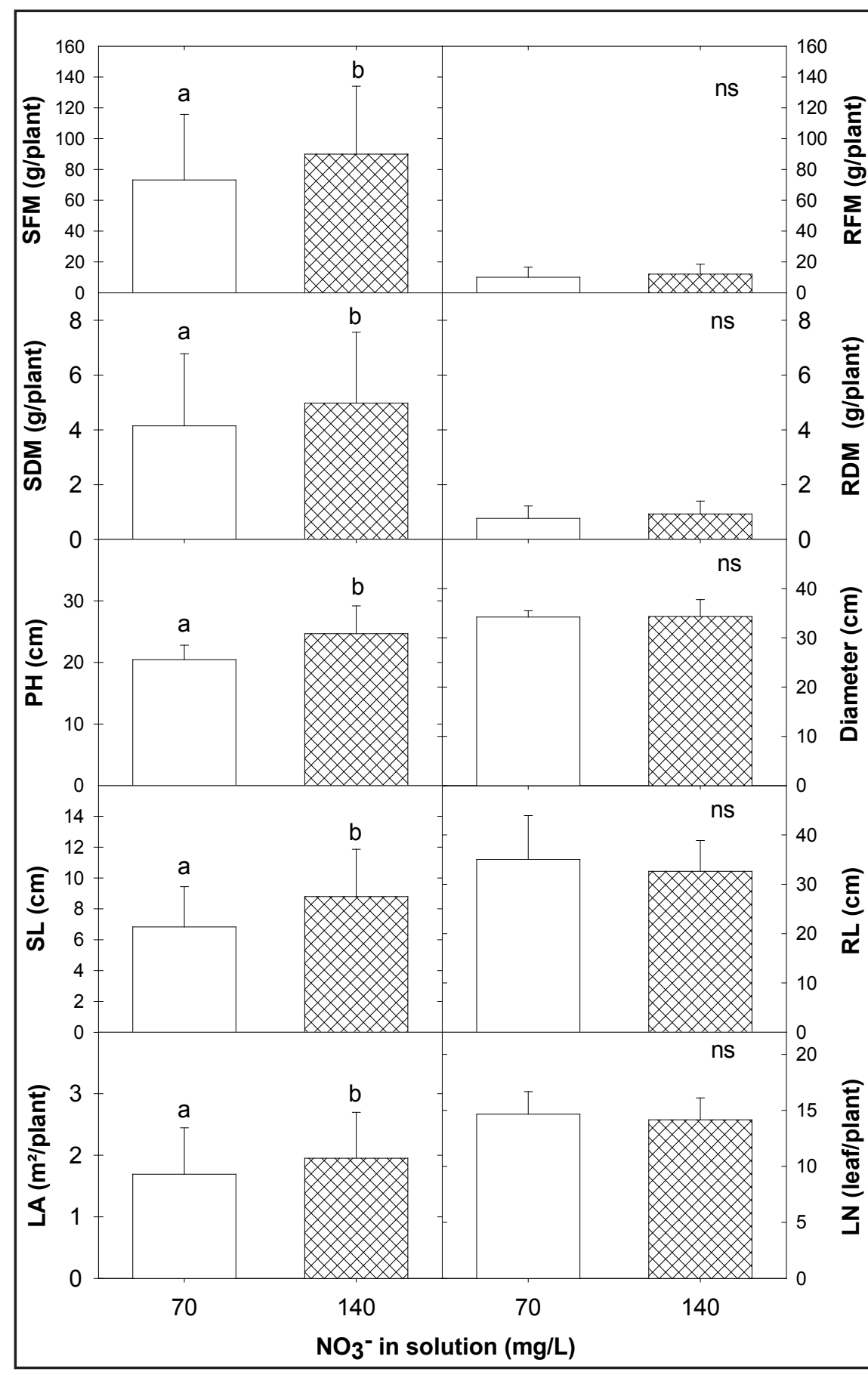

Figure 2. Morphological variables of hydroponic lettuce in function of the nitrate concentration in the nutrient solution: SFM (shoot fresh mass); RFM (root fresh mass); SDM (shoot dry mass); RDM (root dry mass); PH (plant height); SL (stem length); RL (root length); LA (leaf area); LN (number of leaves) (variáveis morfológicas da alface em cultivo hidropônico em função dos teores de nitrato na solução nutritiva. SFM (massa fresca da parte aérea); RFM (massa fresca da raiz); SDM (massa seca da parte aérea); RDM (massa seca da raiz); AP (altura da planta); SL (comprimento do caule); RL (comprimento de raiz); LA (área foliar); LN (número de folhas)). Alegre, UFES, 2009.

SFM raised from 31.9 to 130.2 , SDM from 1.6 to 7.8 , RFM of 3.7 to 19.7 and RDM from 0.3 to $1.4 \mathrm{~g} /$ plant, as shown in Figure 1. Most greenhouses used by hydroponic farmers present incidence greenhouses, reducing productivity as a consequence. Similar results, with lettuce shoot dry matter yield of 10.14 , 7.69 and $3.29 \mathrm{~g} /$ plant were observed in an experiment with shading at zero, 18 and $50 \%$ respectively (Novo et al., 2008). There was also a reduction in biomass production of shoots of lettuce under protected environment when shading increased from 10 to $90 \%$, falling from 225.7 to $81.0 \mathrm{~g} /$ plant (Byrne et al., 2002). The increase in fresh mass production showed a quadratic fit with lower elevation of the fresh weight by raising the PPF, while the dry weight gain followed a linear increase (Figure 1), showing that the difference between the models indicates greater water loss in plants without shading $(\mathrm{PPF}=455$ $\mathrm{mol} / \mathrm{m}^{2} / \mathrm{s}$ ). This can be verified by the surface temperature of leaves in plants without shading (Table 1), whose plants had temperatures from 1 to $2^{\circ} \mathrm{C}$ lower than more shaded plants, due to higher transpiration caused by early stomatal opening of these plants throughout the day, in relation to the shaded plants. On the other hand, the increasing linear dry phytomass production demonstrates that the treatments were not light-saturated yet when in the unshaded treatments, besides the plastic greenhouse and thermal reflective screen. Even though lettuce is a $\mathrm{C} 3$ plant, the saturation point for canopies appears to be close to 1000 $\mu \mathrm{mol} / \mathrm{m}^{2} / \mathrm{s}$ (Frantz et al., 2004). This shows the importance of exchanging greenhouse plastic film and using screens with little shading, thus avoiding crop productivity. Nitrate concentration in the shoot (fresh and dry mass basis) decreased along with increasing PPF with $70 \mathrm{mg} \mathrm{L}^{-1}$ of $\mathrm{N}^{-\mathrm{NO}_{3}}$ - nutrient solution (Figure 1). With $140 \mathrm{mg}$

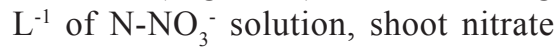
content reduced with increasing levels of PPF. The inflection of the curve would indicate a minimum level and a slight increase tending to stabilize the accumulation of nitrate. The maximum $\mathrm{NO}_{3}{ }^{-}$concentrations in shoot fresh mass were $792.8 \mathrm{mg} \mathrm{kg}^{-1}$ and 966.3 $\mathrm{mg} \mathrm{kg}^{-1}$ when the supplies were 70 and $140 \mathrm{mg} \mathrm{L}^{-1}$ and with PPF of 118 $\mu \mathrm{mol} / \mathrm{m}^{2} / \mathrm{s}$. These levels are below those established by the European Union, whose maximum permissible 
levels vary from 3,500 to $4,500 \mathrm{mg}$ $\mathrm{N}-\mathrm{NO}_{3}{ }^{-} \mathrm{kg}^{-1}$ fresh mass for the winter season and 2,500 mg of $\mathrm{N}-\mathrm{NO}_{3}^{-} \mathrm{kg}^{-1}$ fresh mass for summer crops (Europe, 2009). These values are about $50 \%$ of the maximum value of $1,700 \mathrm{mg} \mathrm{kg}^{-1}$ fresh weight observed in the lettuce cvs. Grandes Lagos, Regina, and Baba de Verão, in an experiment conducted during the autumn in Viçosa, Minas Gerais state, Brazil (Fernandes et al., 2002) and similar to those observed in nutrient solution with $100 \mathrm{mg} \mathrm{L}^{-1}$

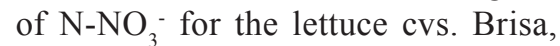
Divina, and Prima, of 940.0, 844.5, and 719.8, respectively (Lastra et al., 2009). Novo et al. (2008) growing lettuce in hydroponics, observed that shading of only $18 \%$ caused a build-up of nitrate above $3,000 \mathrm{mg} \mathrm{kg}^{-1}$, but for us it is difficult to compare these results since the authors did not provide data of radiation incident (PPF). Ohse et al. (2009) observed in the cultivar Vera, in hydroponics without shading, an average shoot nitrate content of 80.22 $\mathrm{mg} \mathrm{kg}^{-1}$, a value below the lowest value observed in this experiment. This shows that in tropical environment under high PPF or protected environment with little shading, there is no accumulation of nitrate at levels of risk to human health. However, Miyazawa et al. (2001) reported that $50 \%$ of the samples of hydroponic lettuce marketed in Curitiba, Paraná state, contained between 6,000 and 9,000 mg kg-1 of nitrate in dry mass basis. This range of values, if simulated by the model showed in Figure 1, would be below $700 \mathrm{mg} \mathrm{kg}^{-1}$ of nitrate in fresh mass basis. Therefore, for consumption purposes, we suggest that nitrate must be analyzed in tissue on a fresh mass basis, thereby avoiding mistakes in interpretation, since the nitrate works as osmoticum and would provide water accumulation in plant tissue (Huang et al., 2010).

In roots, nitrate accumulation on both fresh and dry mass basis followed a quadratic model for the solutions with

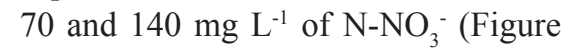
$1)$. The increase of the PPF $(455 \mu \mathrm{mol} /$ $\mathrm{m}^{2} / \mathrm{s}$ ) promoted the reduction of nitrate concentration in the roots, due to the greater availability of photosynthates for assimilation and reducing power for nitrate reductase. However, when the plants were intensively shaded, with $\mathrm{PPF}=118 \mu \mathrm{mol} / \mathrm{m}^{2} / \mathrm{s}$, there was a marked decrease in nitrate concentration, indicating restrictions on nitrate uptake, causing depletion of nitrate in the root to keep its flow towards the shoot. The absorption of nitrate is dependent on light, which can change the ability of low-affinity carriers to absorb nitrate. This suggests an energy-dependent absorption process (Peuker \& Jeschke, 1998), because the influx of nitrate to the roots is an active process, driven by the gradient of $\mathrm{H}^{+}$(Forde, 2002). In contrast, above $118 \mu \mathrm{mol} / \mathrm{m}^{2} / \mathrm{s}$, the accumulation of nitrate in the roots increases, but does not follow linearly the increase of PPF, a pattern opposite to that observed in the shoot. Thus, the root seems to have a buffering effect preventing the accumulation of nitrate in the shoot to levels harmful to plant growth. This effect has been suggested in rhizome of Paspalum notatum (Fernandes et al., 1985), and stem of lettuce in hydroponics (Cometti et al., 2004). This mechanism has been explained as a feedback regulation by products of the assimilation of $\mathrm{N}$ uptaken (Forde, 2002).

Lettuce shoot phytomass (SFM) was significantly higher in $140 \mathrm{mg}$ $\mathrm{L}^{-1} \mathrm{~N}$-nitrate solution (Figure 2). Root fresh and dry mass (RFM and RDM), diameter of the plant, length of roots (RL) and number of leaves (LN) showed no significant differences between the treatments of nitrate in the nutrient solution. These results indicate that the reduction of nitrate in the nutrient solution may decrease lettuce canopy productivity. Therefore, concentrations lower than $140 \mathrm{mg} \mathrm{L}^{-1}$ $\mathrm{N}-\mathrm{NO}_{3}{ }^{-}$are not recommended. Despite the increased production of phytomass by plants grown in solution with 140 $\mathrm{mg} \mathrm{L}^{-1}$ of $\mathrm{N}_{-} \mathrm{NO}_{3}^{-}$, there was no effect in the number of leaves, showing that higher nitrogen was responsible for leaf expansion, as observed for LA. Lettuce cultivars grown in various concentrations of $\mathrm{N}$ in nutrient solution did not show difference for leaf number (Lastra et al., 2009).

Nitrate levels in the nutrient solution had significant influence on nitrate accumulation in shoot and roots, reaching the highest values with $140 \mathrm{mg} \mathrm{L}^{-1}$ of nitrate (Figure 1). The $\mathrm{NO}_{3}$ - dissolved in water facilitates the root uptake, which means there is an absorption of amounts above the plant's ability to reduce $\mathrm{NO}_{3}{ }^{-}$to $\mathrm{NH}_{4}^{+}$, thus accumulating the surplus in the plant tissue (Miyazawa et al., 2001). Thus, larger amounts of $\mathrm{NO}_{3}^{-}$in the nutrient solution cause greater root uptake. The low-affinity ion transporters involved in $\mathrm{N}$ uptake at concentrations above $1.0 \mathrm{mmol} \mathrm{L}^{-1}$ (Peuker \& Jeschke, 1998), gain importance in hydroponics, and thus the increase of 5 to $10 \mathrm{mmol} \mathrm{L}^{-1}$ carried out in this trial may explain the difference in accumulation of nitrate in the shoot of lettuce. This mechanism of $\mathrm{N}-\mathrm{NO}_{3}{ }^{-}$uptake is induced by external nitrate concentration and regulated by feedback by the products of $\mathrm{N}$ assimilation (Forde, 2002).

In summary, the reduction of light led to the increase of nitrate accumulation in the leaves, but even at low levels of photosynthetic photon flux, 118 $\mathrm{mol} \mu \mathrm{mol} / \mathrm{m}^{2} / \mathrm{s}$, there was not nitrate accumulation above the European Union parameters. The maximum concentration of nitrate found in this study (966.3 $\mathrm{mg} \mathrm{kg}^{-1}$ fresh matter at $\mathrm{PPF}=118 \mu \mathrm{mol} / \mathrm{m}^{2} / \mathrm{s}$ and $140 \mathrm{mg} \mathrm{L}^{-1}$ de $\mathrm{N}-\mathrm{NO}_{3}$ - in nutrient solution) does not represent risk for human consumption of hydroponics lettuce in tropical environment conditions. Decreasing nitrate in the nutrient solution from 140 to $70 \mathrm{mg} \mathrm{L}^{-1}$ led to reduction of nitrate accumulation on leaves, but also decreased shoot phytomass production, as well as leaf area.

\section{ACKNOWLEDGEMENTS}

Dr. Dirceu Pratissoli for making the greenhouse available; Mr. Silvio Rogério Ferraz and Mrs. Sônia Maria da Silva for their help in laboratory tests; Dr. Jonathan M. Frantz and Dr. Fernando Dantas de Araújo for manuscript review.

To CAPES and FAPES for the master's scholarships for the second and third authors, respectively.

\section{REFERENCES}

ADDISCOTT T. 2006. Is it nitrate that threatens 
life or the scare about nitrate? Journal of Science and Food Agriculture, 86: 2005-2009.

ANDRIOLO JL. 1999. Fisiologia das culturas protegidas. Santa Maria: UFSM, 142p.

BENINNI ERY; TAKAHASHI HW; NEVES CSVJ; FONSECA ICB. 2002. Teor de nitrato em alface cultivada em sistemas hidropônico e convencional. Horticultura Brasileira, 20: 183-186.

BYRNE C; MAHER MJ; HENNERTY MJ; MAHON MJ; WALSHE PA. 2002. Reducing the nitrate content of protected lettuce. Irish Agriculture and Food Development Authority. Dublin: University College, $19 \mathrm{p}$.

CATALDO DA; HAROON M; SCHRADER LE; YOUNGS VL. 1975. Rapid colorimetric determination of nitrate in plant tissue by nitration of salicylic acid. Communications in Soil Science and Plant Analysis, 6: 71-80.

COMETTINN; FURLANI PR. 2009a. Hidroponia e segurança alimentar. In: FERREIRA A; LIMA ABP; MATTA FP; AMARAL JAT; LOPES JC; PEZZOPANE JEM; FERREIRA MFS; POLANCZYK RA; SOARES TCB. Tópicos Especiais em Produção Vegetal I.1 ed. Alegre, ES : Centro de Ciências Agrárias. p. $517-528$.

COMETTI NN; FURLANI PR. 2009b. Planilha interativa para cálculo de solução nutritiva. Disponível em http://www.niltoncometti.com. br/software/solucaonutritiva.xls Acessado em: 09 de junho de 2010.

COMETTI NN; MATIAS GCS; ZONTA E; MARY W; FERNANDES MS. 2004. Compostos nitrogenados e açúcares solúveis em tecidos de alface orgânica, hidropônica e convencional. Horticultura Brasileira 22: 748-753.

EUROPA. European Union scientific for food.
2009. Opinion on nitrate and nitrite (expressed on 22 September 1995). Disponível em http:// ec.europa.eu/ Acessado em: 09 de junho de 2010.

FERNANDES AA; MARTINEZ HEP; PEREIRA PRG; FONSECA MCM. 2002. Produtividade, acúmulo de nitrato e estado nutricional de cultivares de alface, em hidroponia, em função de fontes de nutrientes. Horticultura Brasileira 20: $195-200$.

FERNANDES MS; ROSSIELLO ROP; BENDIX MES. 1985. Effects of N-Source, light intensity and temperature on nitrogen metabolism of bahiagrass. Journal of Plant Nutrition 8: 945-963.

FORDE BG. Local and long-range signaling pathways regulating plant responses to nitrate. 2002. Аnnu. Rev. Plant Biol. 53: 203-24.

FRANTZ JM; RITCHIE G; COMETTI NN; ROBINSON J; BUGBEE B. 2004. Exploring the limits of crop productivity: beyond the limits of tipburn in lettuce. $J$ Am Soc Hortic Sci. 129: 331-8.

FURLANI PR; SILVEIRA LCP; BOLONHEZI D; FAQUIN V. 1999. Cultivo hidropônico de plantas. Campinas: Instituto Agronômico. 52 p. (Boletim técnico, 180).

HUANG CB; WANG ZH; LI SX; MALHI SS. 2010. Nitrate in leaf petiole and blade of spinach cultivars and its relation to biomass and water in plants. Journal of Plant Nutrition, 33: 1112-1123.

LASTRA O; TAPIA ML; RAZETO B; ROJAS M. 2009. Response of hydroponic lettuce cultivars to different treatments of nitrogen: growth and foliar nitrate content. Idesia 27: 83-89.

LUZ GL; MEDEIROS SLP; MANFRON PA; MULLER ADAL; TORRES MG; MENTGES L. 2008. A questão do nitrato em alface hidropônica e a saúde humana. Ciência Rural 38: 2388-2394.

MIYAZAWA M; KHATOUNIAN CA; ODENATH-PENHA LA. 2001. Teor de nitrato nas folhas de alface produzida em cultivo convencional, orgânico e hidropônico. Agroecologia Hoje. Ano II, N. 7, p. 23.

NOVO AAC; MEDEIROS JF; SOUZA CHE; PEREIRA PRG; MARTINEZ HEP; FONTES PCR; COMETTI NN. 2008. Influência do sombreamento sobre o crescimento e teores de nitrato em hortaliças folhosas em hidroponia. Revista Universo Acadêmico. Edição ${ }^{\circ} 13$. Disponível em http://www.univen.edu.br/ revista/n013. Acessado em 09 de dezembro de 2009.

OHSE S. 2000. Qualidade nutricional e acúmulo de nitrato em alface hidropônica. In: SANTOS O (ed). Hidroponia da alface. Santa Maria: Impr. Univ. UFSM. p. 10-24.

OHSE S.; RAMOS DMR; CARVALHO SM; FETT R; OLIVEIRA JLB. 2009. Composição centesimal e teor de nitrato em cinco cultivares de alface produzidas sob cultivo hidropônico. Bragantia 68: 407-414.

PEUKE AD; JESCHKE WD. 1998. The effects of light on induction, time courses, and kinetic patterns of net nitrate uptake in barley. Plant, Cell and Environment 21: 765-774.

ROORDA Van; EYSINGA JPNL. 1984. Nitrate and glasshouse vegetables. Fertilizer Research 5: 149-156.

SANTAMARIA P. 1997. Contributo degli ortaggi all' assunzione giornaliera di nitrato - nitrito e nitrosamina). Industrie-Alimentari 36: 1.329-1.334.

WRIGHT MJ; DAVISON KL. 1964. Nitrate accumulation in crops and nitrate poisoning in animals. Advances in Agronomy 16: 197-274. 